\title{
The Primary School Pupils' Knowledge and Attitudes on Selected Textile Topics
} Znanje in stališča osnovnošolcev do izbranih tekstilnih vsebin

\author{
Short Scientific Article /Kratki znanstveni prispevek \\ Received/ Prispelo 04-2015 • Accepted/Sprejeto 10-2015
}

\begin{abstract}
The purpose of this study was to examine how primary school children who had already finished learning about textile topics during Home economics instruction perceived the content of the textile module. Some topics which can be connected with development of sustainable thinking and prudent consumer behaviour were also researched. A total of 106 surveys were collected. The pupils were on average 10.5 years old. The results showed that the pupils were reasonably interested in handicrafts. Most respondents agreed that mastering skills such as sewing or knitting is good because these activities allow pupils to save money and also to express their creativities. The results showed that the transfer of theoretical knowledge in practice is not optimal. Some improvements in the curriculum should be considered in terms of refreshing/updating the textile topics and also the time duration of the textile module.

Keywords: education, handicraft, textile, sustainability
\end{abstract}

\section{Izvleček}

Namen predstavljene raziskave je bil ugotoviti, kako otroci, ki obiskujejo devetletno osnovno šolo in ki so že zaključili spoznavanje tekstilnih vsebin, zaznavajo vsebine tekstilstva pri predmetu gospodinjstvo. V raziskavi je sodelovalo 106 učencev. V povprečju so bili stari 10,5 let. Rezultati so pokazali, da se je večina učencev strinjala, da obvladovanje ročnih spretnosti lahko omogoča denarni prihranek in tudi možnost izražanja lastne kreativnosti. Namen raziskave je bil tudi ugotoviti povezavo med izbranimi tekstilnimi vsebinami in trajnostnim vedenjem. Pokazalo se je, da prenos znanja v tem kontekstu ni zadovoljiv. Zato bi bil v prihodnosti potreben razmislek o izpopolnitvi/osvežitvi tekstilnih vsebin učnega načrta za gospodinjstvo, ravno tako bi bil potreben razmislek o ustreznosti števila ur, ki so namenjene temu področju.

Ključne besede: izobraževanje, ročne spretnosti, tekstil, trajnost

\section{Introduction}

Throughout their lives people encounter many textile products. The area of textiles is interdisciplinary [1]. Clothes play a very important part in textile products for everyone. Clothing has not only a practical, protective role but also according to Todorović, Toporišič and Pavko Čuden [2]: "Through clothing, a person can make his/her first step in non-verbal communication towards the world." or according to Eun-Young Rhee [3]: Clothes have special meanings

Corresponding author/Korespondenčna avtorica:

D.Sc. Francka Lovšin Kozina

Telephone: 0038615892212

E-mail:francka.lovsin@pef.uni-lj.si to individuals and groups. Human beings have used clothing for protective and symbolic reasons since prehistoric times. In current societies, consumers enjoy hedonistic pleasure and self-expression with fashion products. Martin and Bush [4] stated that young consumers are the more concerned with trends. However, there are problems related to the rapid growth of textile waste $[5,6]$. The problem lies in the production of cheap clothing (fast fashion) where synthetic, difficult to recycle textile materials are used [7].

Tekstilec, 2015, letn. 58(4), str. 274-280

DOl: 10.14502/Tekstilec2015.58.274-280 
There is a need to educate people about the importance of wise purchasing, maintenance and handling of textiles so that they will be able to effectively use their knowledge at different life stages of the textile product. Some researchers have shown that consumers are concerned about the environment but this does not mean that consumers will also purchase environmentally-responsible products $[8,9]$. To overcome this gap, education might be helpful. Ellen et al. [10] stated that greater knowledge by consumers positively impacts their feeling that they can control and overcome the difficulties related to environmentally-sustainable textiles and apparel consumption. Similarly, the results of a Kang et al. [11] study indicated that: "consumers' product knowledge, perceived consumer effectiveness and perceived personal relevance significantly affected young consumers' attitudes, subjective norms and perceived behavioural control, thereby affecting purchase intentions for environmentally sustainable textiles and apparel".

It is also very important to build a system for organising waste collection which can be useful and wellknown to pupils. Research on consumers' clothing disposal behaviour [12] based on a review of the empirical literature published over the last 30 years, shows that consumers prefer to deliver clothing for reuse (donate, give to friends) - one of the detected reasons for this decision was that consumers were unaware of other options such as recycling. Morgan, Birtwistle [7] stated that people were more likely to retain expensive clothing for a longer time, the cheaper clothing usually being worn as long as they were wearable. They mentioned three main reasons for stopping the wearing of cheap clothing: lower quality, new fashion trends and clothes for one-off events. They also found that people tended to discard cheaper clothes, while they tended to donate more expensive clothes.

Forte Tavčer [13] stated that the result of organised, efficient waste collection allows reuse and recycling, which among others help to protect the environment (conservation of natural resources, reduction of the harmful effects of waste generation), the creation of new "green" jobs and cost reduction (low cost materials, lower environmental taxes).

The ecological aspect is one of the basic principles of Home economics (7E), also stated in the Home Economics curriculum [14]: the equality of gender, equality of common work, economy (economics), ecological aspects (sustainability), ergonomics, ethics, aesthetics and culture. The Textile and clothing course is divided into the following content topics [14]:

- fibres (sources and properties),

- mechanical processing of fibre (spinning, weaving, knitting, felting),

- finishing goods (dyeing, printing ...),

- recycling apparel and other textile products,

- innovations within the textile industry,

- designing and fashion,

- footwear and fashion accessories,

- conscious shopping for textile products; consumer resource management.

The environmental aspect can be introduced in all stated topics. The pupils can obtain ideas on environmentally-friendly textile production, consumption and recycling. They can also get ideas on how to make some products themselves. The module of textiles not only allows getting theoretical knowledge of textile topics, the developing of sustainable behaviour regarding pupils but it also encourages the pupils' creativities. Creativity is associated with spontaneity, originalcreative thinking, and problem solving $[15,16]$. Pupils can thus solve different case studies (e.g. how we can produce green fashion), make some practical products using different textile techniques (felting, dyeing, knitting); obtain knowledge through experiential learning or through "the process whereby knowledge is created through the transformation of experience." [17].

Nowadays, for example, researchers explore the connections between knitting and the brain. Knitting is a repetitive activity during which psychomotor and cognitive skills are developed. There is some evidence that creative arts can positively impact mental health and well-being [18]. Rilley, Corkhill and Morris [19] research conducted amongst 3,545 knitters worldwide showed:

- The knitter who knitted frequently reported more often that they felt calm after knitting.

- Knitting can help coping with stress and improving one's mood; $46 \%$ of respondents stated that the texture affected their mood, while $24 \%$ of respondents stated that colour affected their mood.

- The majority of respondents stated the positive effects of knitting on concentration, thought, memory and coping with emotions ("emotional control").

- Knitting had a higher positive social aspect when the knitting was done in knitting groups.

- Knitting improved some cognitive skills (mathematical skills, planning, organisational, and visual/spatial awareness). 
- Knitting also encouraged creativity.

- Involvement in a creative occupation such as knitting can contribute positively to the personal and social well-being of people.

Teaching textile topics can be so valuable for the pupils' well-beings for different reasons. It can help them:

- to handle everyday routines (hygiene, clothes combination, self expression ...),

- to develop sustainable thinking and behaviour,

- to develop healthy attitudes to fashion and consumerism

- to develop creative thinking.

As was stated several researches among adults on textile topics, involved also in Home economics subject (consumer behaviour, sustainability, practical work - creativity etc.), was conducted in recent years. However, there remains need for an investigation of knowledge and attitudes on textile topics of primary school children. Formal education might help to develop sustainable oriented thinking, encourage creativity etc. But, the educational outcome depends also on how pupils perceive some topics, their experiences, learning with observation (also from role models like are parents), the possibility of transferring the new knowledge into the real life, etc. The aim of the presented study was to research how pupils perceived textile topics integrated in Home Economics subject, especially how they perceived selected practical skills related to the textile content of Home Economics, what experiences they have with handling textile from home, how prudent consumers they are - how effectively transfer knew knowledge into practice (for example reading the information on declarations).

\section{Experimental}

The survey-based pilot research was conducted amongst 106 pupils who had yet to finish with the textiles module in home economics $\left(5^{\text {th }}\right.$ and $6^{\text {th }}$ classes). They were on average 10.94 years old. 61 $(57.5 \%)$ boys and $44(41.9 \%)$ girls answered the questionnaire. The questionnaire consisted of the following sections:

- The pupils' demographic and socioeconomic characteristics.

- The pupils were asked about their ages, genders.

- The pupils' actual transfer of knowledge into practice.
- The pupils were asked about their behavior when they go to shop for textile products.

- The pupils' experiences from home.

- The pupils were asked who teaches them some practical skills at home, whether they try at home some in-school learned activities and what experiences they have with managing old textiles.

- The pupils' attitudes on practical skills.

The question types were closed answers; offering Likert scale and short answers. The data were analysed using the SPSS statistical program. For analysis, A descriptive and frequency analysis was used for analysis. Further analyses involved $t$ - tests where the significance level of $\alpha=0.05$ was used.

\section{Results and discussion}

The purpose of education is the transfer of textile knowledge into practice to improve the well-being of the individual. Two aspects are important: developing theoretical and practical knowledge which helps to increase the independence of the individual and the development of sustainable oriented thinking and behaviour.

One of the recent problems is the treatment of clothes. Thinking about waste textiles should start before making a purchase. According to Philippe and Ngobo [20] consumer knowledge consist of product knowledge and familiarity with a product and is a critical factor for sustainable consumption [21]. Within this context the pupils are alerted to the importance of knowing which information can be found in the declaration on the garment and the way they should read the declarations, the environmental impact of proper handling with (waste) textiles, and the impact of fast fashion on the environment. The pupils were asked whether they read the declarations before purchasing a textile product. This question was answered by 96 pupils and the result showed that before buying textile product $79(82.3 \%)$ checked the information on the declarations, 17 (17.7\%) did not. 43 (40.9\%) of 105 pupils stated that the knowledge of clothing maintenance (that they learned in Home economics) was already being used at home.

As can be seen from Table 1, information on the declaration doesn't have the biggest impact on the purchasing decisions of the pupils. The most decisive factor for the pupils was the appearance. This is unsurprising because of the developmental characteristics of pupils. 
Table 1: Textile purchasing decision factors

\begin{tabular}{|c|c|c|c|c|c|c|c|c|c|}
\hline \multirow[t]{2}{*}{ Decision factor } & \multirow[t]{2}{*}{$\mathrm{N}$} & \multicolumn{2}{|c|}{ No impact } & \multicolumn{2}{|c|}{$\begin{array}{l}\text { Little } \\
\text { impact }\end{array}$} & \multicolumn{2}{|c|}{ Impact } & \multicolumn{2}{|c|}{$\begin{array}{l}\text { Strong } \\
\text { impact }\end{array}$} \\
\hline & & $\mathrm{f}$ & $\%$ & $\mathrm{f}$ & $\%$ & $\mathrm{f}$ & $\%$ & $\mathrm{f}$ & $\%$ \\
\hline Appearance & 105 & 1 & 1.0 & 6 & 5.7 & 30 & 28.6 & 68 & 64.8 \\
\hline Price & 104 & 2 & 1.9 & 21 & 20.2 & 51 & 49.0 & 30 & 28.8 \\
\hline $\begin{array}{l}\text { Information on maintenance; } \\
\text { declarations }\end{array}$ & 105 & 14 & 13.3 & 27 & 26.7 & 35 & 33.3 & 29 & 27.6 \\
\hline Seller advice & 104 & 21 & 20.2 & 31 & 29.9 & 41 & 39.4 & 11 & 10.6 \\
\hline The possibility of recycling & 103 & 29 & 28.2 & 26 & 25.2 & 24 & 23.3 & 24 & 23.3 \\
\hline Country of manufacture & 105 & 52 & 49.5 & 25 & 23.8 & 18 & 17.1 & 10 & 9.5 \\
\hline Friend's opinion & 105 & 49 & 46.7 & 34 & 32.4 & 14 & 13.3 & 8 & 7.6 \\
\hline Film actors, singers & 104 & 64 & 61.5 & 18 & 17.3 & 11 & 10.6 & 11 & 10.6 \\
\hline Advertisements & 104 & 63 & 60.6 & 28 & 26.9 & 9 & 8.7 & 4 & 3.8 \\
\hline
\end{tabular}

Table 2: Pupils opinions on the role of appearance in their lives

\begin{tabular}{|l|c|c|c|}
\hline \multirow{2}{*}{ Statement } & \multirow{2}{*}{$\mathrm{N}$} & \multicolumn{2}{|c|}{ I agree } \\
\cline { 3 - 4 } & $\mathrm{f}$ & $\%$ \\
\hline $\begin{array}{l}\text { I dress just as I like, } \\
\text { regardless of the opinions } \\
\text { of others. }\end{array}$ & 104 & 88 & 83.1 \\
\hline $\begin{array}{l}\text { I dress in accordance with } \\
\text { the expectations of others. }\end{array}$ & 104 & 12 & 11.3 \\
\hline $\begin{array}{l}\text { The other pupils would } \\
\text { make fun of me if I were } \\
\text { dressed differently to them. }\end{array}$ & 91 & 35 & 33.0 \\
\hline
\end{tabular}

But Schor [22] exposed problems related to the brands in pupils' lives. She stated that school spaces have been transformed into brand showrooms which may have a negative effect on the social divisions amongst groups and which may lead also to bullying and social exclusion. The pupils were also asked their opinions on the role of appearance in a pupil's life. As can be seen from Table 2 most of the pupils agreed that they dress just as they like, regardless of the opinions of others. On the question related to bullying only 91 pupils answered but there was a relatively high percentage of the pupils who agreed that other pupils would poke fun of them if they were dressed differently from how they were. From a sustainable point of view, it is very important how people handle clothes. As was mentioned the modern man is faced with the trend of fast fashion [7] and problems with growing waste $[5,6]$. The pupils were asked how long they keep their clothes. This question was answered by 105 pupils and most pupils, i.e. $73(69.5 \%)$ stated that they keep their clothes until they are completely worn out. The pupils were also asked what they did with their old clothes at home. As can be seen from Table 3, consumers preferred to

Table 3: Treatment of waste clothes

\begin{tabular}{|l|c|c|c|c|c|c|c|c|c|}
\hline \multirow{2}{*}{ Option } & \multirow{2}{*}{$\mathrm{N}$} & \multicolumn{2}{c|}{ Never } & \multicolumn{2}{c|}{ Sometimes } & \multicolumn{2}{c|}{ Often } & \multicolumn{2}{c|}{ Always } \\
\cline { 3 - 10 } & & $\mathrm{f}$ & $\%$ & $\mathrm{f}$ & $\%$ & $\mathrm{f}$ & $\%$ & $\mathrm{f}$ & $\%$ \\
\hline We donate old clothes. & 103 & 5 & 4.9 & 18 & 17.5 & 50 & 48.5 & 30 & 29.1 \\
\hline $\begin{array}{l}\text { Take old clothes to the recycling } \\
\text { centre. }\end{array}$ & 103 & 30 & 29.1 & 25 & 24.1 & 30 & 29.1 & 18 & 17.5 \\
\hline $\begin{array}{l}\text { We recycle old clothes. } \\
\text { (Sew something else ...). }\end{array}$ & 76 & 35 & 46.1 & 28 & 36.8 & 8 & 10.5 & 4 & 6.6 \\
\hline $\begin{array}{l}\text { We throw them in a container for } \\
\text { "other waste". }\end{array}$ & 104 & 66 & 63.5 & 29 & 27.9 & 6 & 5.8 & 3 & 2.9 \\
\hline We burn old clothes. & 104 & 101 & 97.1 & 2 & 1.9 & 1 & 1.0 & 0 & 0 \\
\hline
\end{tabular}


donate their old clothes, which is in line with the Laitala [12] research results.

On the question: "Which practical activities did you do during the Home economics hours?" most pupil (91.5\%) stated sewing on a button. 34\% of pupil stated that they sewed a textile product, $26.4 \%$ of pupil did weaving, felting 25.5\%, 23.6\% dyeing, printing $21.7 \%$, and $16.9 \%$ knitting. The first three more interesting practical activities for pupils that they did at school were sewing on buttons (31.9\%), weaving (19.6\%), and dyeing (15.5\%).

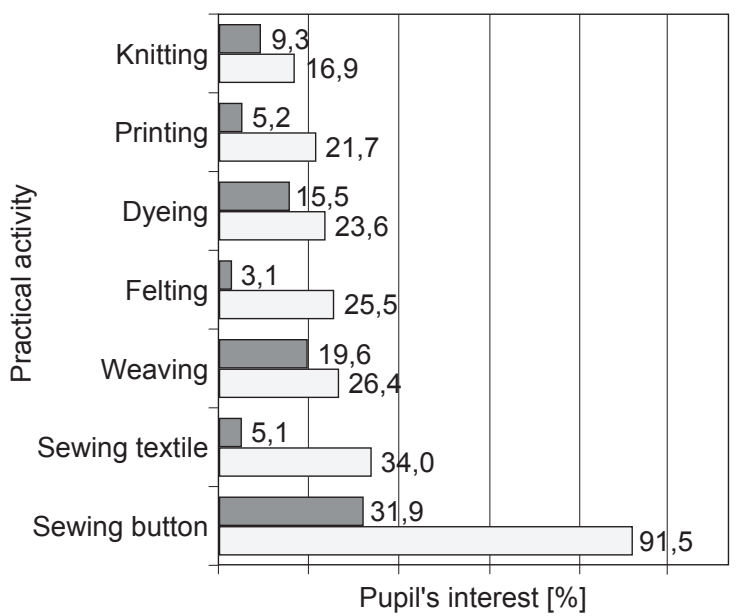

Figure 1: The Most atractive $\square$ Realized

realised and more attractive activities $(N=106)$

Table 4: The person who taught the child some textile techniques

\begin{tabular}{|l|r|r|}
\hline \multicolumn{1}{|c|}{ Person } & F & $\%$ \\
\hline Grandmother & 45 & 48.9 \\
\hline Mother & 40 & 43.5 \\
\hline Aunt & 2 & 2.1 \\
\hline Father & 1 & 1.1 \\
\hline Cousin & 1 & 1.1 \\
\hline Great-grandmother & 1 & 1.1 \\
\hline My mother's aunt & 1 & 1.1 \\
\hline Friend & 1 & 1.1 \\
\hline Together & 92 & 100 \\
\hline
\end{tabular}

The pupils were asked to answer who taught them some textile techniques at home. This question was answered by only 92 pupils and as can be seen from Table 4 the most important persons were grandmother and mother. Only one pupil said that his father showed him how to print on textile.

The pupils were also asked how they perceived mastering practical skills. The results showed (Table 5) that most of the pupils agreed that by mastering some practical skills someone could save money and that mastering some practical skill also allows someone to express their creativity. Most of the pupils also agreed with statement that: "If I helped to reduce the exploitation of textile workers in developing countries by making garments on my own, I would do this."

Table 5: Pupils opinions on mastering practical skills

\begin{tabular}{|l|c|c|c|}
\hline \multicolumn{1}{|c|}{ Statement } & $\mathrm{N}$ & $\mathrm{f}$ & $\%$ \\
\hline $\begin{array}{l}\text { Mastering skills such } \\
\text { as sewing or knitting } \\
\text { is good - you can save } \\
\text { money. }\end{array}$ & 106 & 87 & 82.1 \\
\hline $\begin{array}{l}\text { Mastering skills such } \\
\text { as sewing or knitting, } \\
\text { etc. allows someone } \\
\text { to express their } \\
\text { creativity. }\end{array}$ & 106 & 81 & 76.4 \\
\hline $\begin{array}{l}\text { Today, textile products } \\
\text { are so cheap that } \\
\text { there is no sense } \\
\text { wasting time and money } \\
\text { on learning sewing, } \\
\text { knitting... }\end{array}$ & 105 & 20 & 19.0 \\
\hline $\begin{array}{l}\text { If I helped to reduce } \\
\text { the exploitation } \\
\text { of textile workers } \\
\text { in developing countries } \\
\text { by making garments } \\
\text { on my own, I would } \\
\text { do this. }\end{array}$ & 104 & 66 & 63.5 \\
\hline
\end{tabular}

As can be seen from Table 6 a small share of the surveyed children agreed that handicrafts didn't interest them, and that they didn't like practical work because they were unsure that they would make a good product. What is statistically significant about this statement is that more boys agreed than girls $(\mathrm{t}=2.552, \mathrm{df}=100, \mathrm{p}=0.006)$. More boys also significantly agreed statistically than girls that the content of textile is to hard $(t=1.981$, $\mathrm{df}=101, \mathrm{p}=0.025)$. 
Table 6: The pupils' attitudes to practical skills

\begin{tabular}{|l|c|c|c|}
\hline \multicolumn{1}{|c|}{ Statement } & N & f & $\%$ \\
\hline $\begin{array}{l}\text { In the school there should } \\
\text { be greater emphasis on } \\
\text { maintaining skills such as } \\
\text { sewing or knitting. }\end{array}$ & 106 & 47 & 44.3 \\
\hline I wish more practical work. & 106 & 47 & 44,3 \\
\hline $\begin{array}{l}\text { I am disinterested in } \\
\text { handicraft. }\end{array}$ & 105 & 27 & 25.7 \\
\hline $\begin{array}{l}\text { I don't like practical work } \\
\text { because I'm not sure that } \\
\text { I will make a good product. }\end{array}$ & 103 & 24 & 23.3 \\
\hline $\begin{array}{l}\text { I am interested in } \\
\text { occupations related to } \\
\text { textile science (seamstress, } \\
\text { designer, scientist ...). }\end{array}$ & 101 & 14 & 13,8 \\
\hline
\end{tabular}

Less than half of the surveyed pupil stated that they wished for more practical work and a very small share of the surveyed pupil expressed interest in occupations related to textile science. The results of this pilot study provide various implications for further research. The next step for future studies would be to determine how learned topics impact the pupil's sense of independence (in the purchasing process, textile maintenance, self-expression ...), what is the parent's role in the transfer of knew knowledge into practice; how many tasks they delegate to the pupils and how they assess the usefulness of the textile content (theory and practical work).

\section{Conclusion}

The results of the presented study showed that the children were not disinterested in handicraft. Most respondents agreed that mastering skills such as sewing or knitting is good because these activities allow pupils to save their money and also to express their creativities. This might be important for children living in a consumer-oriented society. One of the teaching goals in the Home Economics subject is also to give the children the knowledge to be wise and prudent consumers. The results showed that there are possibilities of improving the teaching strategies in terms of the development of sustainable behaviour. The existing curriculum of Home Economics in the $5^{\text {th }}$ grade of nine-year primary school is more theoretically oriented. Upgrading some topics should be considered and also to give more time for some practical creative textile techniques.

\section{References}

1. HEIMDAL, Elisabeth Jacobsen. Interactive inspirational tool for responsive textiles: master's thesis. Lyngby: Technical University of Denmark, Department of Management Engineering, 2009.

2. TODOROVIĆ, Tijana, TOPORIŠIČ, Tomaž, PAVKO ČUDEN, Alenka. Clothes and costumes as form of nonverbal communication. Tekstilec, 2014, 57(4), 321-333, doi: 10.14502/ Tekstilec2014.57.321-333.

3. EUN-YOUNG, Rhee. Clothing and textiles education in South Korea: Perspectives for the knowledge-based information society. Clothing and Textiles Research Journal, 2008, 26(2), 191-200, doi: 10.1177/0887302X08315178.

4. MARTIN, A. Craig, BUSH, J. Alan. Do role model influence teenagers' purchase intention and behaviour. Journal of Consumers Marketing, 2000, 17(5), 441-453, doi: 10.1108/07363760010341081.

5. POULTER, Sean. The primark effect: throwaway fashion that cannot be recycled now make up 30 percent of the waste in council tips. Daily Mail, 2008, 25 [online] [accessed 15. 3. 2015]. Available on World Wide Web: <http://www. dailymail.co.uk/news/article-1089094/ThePrimark-effect-Throwaway-fashion-recycledmakes-30-cent-waste-council-tips.html>.

6. Textile recycling information sheet. Waste online [online] [accessed 15. 3. 2015]. Available on World Wide Web: <http://www.waste online. org.uk/>.

7. MORGAN, R. Louise, BIRTWISTLE, Grete. An investigation of young fashion consumers' disposal habits. International Journal of Consumer Studies, 2009, 33( 2), 190-198, doi: 10.1111/j. 1470-6431.2009.00756.x.

8. BUTLER, Sara M., FRANCIS, Sally. The effect of environmental attitudes on apparel purchasing behaviour. Cloathing and Textile Reserach Journal, 1997, 15(2), 76-85, doi: 10.1177/ $0887302 X 9701500202$.

9. VERMEIR, Iris, VERBEKE, Wim. Sustainable food consumption among young adults in Belgium: Theory of planned behaviour and the role 
of confidence and values. Ecological Economics, 2008, 64(3), 542-553, doi: 10.1016/j.ecolecon. 2007.03.007.

10. ELLEN SHOLDER, Ellen, WIENER, Joshua Lyle, COBB-WALGREN, Cathy. The role of perceived consumer effectiveness in motivating environmentally conscious behaviors. Journal of Public Policy \& Marketing, 1991, 10(2), 102-117.

11. KANG, Jiyun, CHUANLAN, Liu, SANGHOON, Kim. Environmentally sustainable textile and apparel consumption: the role of consumer knowledge, percived consumer effectivness and percived personal relevance. International Journal of Consumer studies, 2013, 37, 442-452, doi: 10.1111/ijcs.12013.

12, LAITALA, Kirsi. Consumers' clothing disposal behaviour - a synthesis of research results. International Journal of Consumer Studies, 2014, 38(5), 444-457, doi: 10.1111/ijcs.12088.

13. FORTE TAVČER, Petra. Zbiranje potrošniških tekstilnih odpadkov v zbirnih centrih po Sloveniji. Tekstilec, 2013, 57(1), 43-61.

14. UČNI NAČRT. Program osnovna šola. Gospodinjstvo. Ljubljana : Ministrstvo za šolstvo in šport : Zavod RS za šolstvo, 2011.

15. PEČJAK, Vid. Misliti, delati, živeti ustvarjalno. Ljubljana : DZS, 1987, 301.
16. WOOLFOLK, Anita. Pedagoška psihologija. Ljubljana: Educy, 2002, 610.

17. KOLB, A. David. Experiential learning: Experience as the source of learning and development. New Jersey: Prentice-Hall, 1984.

18. PERUZZA, Nadia, KINSELLA, Elisabeth Anne. Creative arts occupations in therapeutic practice: a review of the literature. British Journal of Occupational Therapy, 2010, 73(6), 261-268, doi: 10.4276/030802210X12759925468943.

19. RILLEY, Jill, CORKHILL, Betsan, MORRIS, Clare. The benefits of knitting for personal and social wellbeing in adulthood: Finding from an international survey. British Journal of Occupational Therapy, 2013, 76(2), 50-57.

20. PHILIPPE, Aurier, NGOBO, Paul-Valentin. Assesment of consumer knowledge and its consequences: a multi-component approach. Advances in Consumer Research, 1999, 26, 569-575.

21. BATOR, J. Renee, CIALDINI, B. Robert. The application of persuasion theroy to the development of effective proenvironmental public service announcements. Journal of Social Issues, 2000, 56(3), 527-541, doi: 10.1111/0022-4537.00182.

22. SCHOR, B. Juliet. Born to buy: the commercilized child and the new consumer colture. New York : Scribner, 2004, 712-728. 